\title{
WOMEN EMPOWERMENT WITH REFERENCE TO EDUCATION: AN ANALYSIS
}

\author{
Dr. Hitesh Chandra Kalita \\ HOD \&Associate Professor in Philosophy \\ MNC BalikaMahavidyalaya, Nalbari, Assam, India
}

\begin{abstract}
The work on 'women empowerment and education' is tried to establish the means of women empowerment with the help of proper education system. Empowerment is simply the actualization of the potentialities. Education is a systematic way to get the highest knowledge.
\end{abstract}

Keywords: Women empowerment, education and goal of women.

Cite this Article: Dr. Hitesh Chandra Kalita, Women Empowerment with Reference to Education: An Analysis, Journal of Management (JOM), 6 (4), 2019, pp. 1-4. http://www.iaeme.com/JOM/issues.asp?JType=JOM\&VType=6\&IType=4

\section{INTRODUCTION}

The study on it took a formal shape in recent times getting popularity the world over. The emergence of Feminism mainly popularized it the whole world after the end of Second World War. It is an attempt how to empower for getting goal as such highest pleasure, equal dignity with the other sex, freedom of will etc.

\section{METHOD}

I took descriptive, analytical and rational method to study it. To get it has been taken secondary data. All these data are collected from book, journal, internet and empirical aspects.

\section{OBJECTIVES}

- To study the concept women empowerment.

- To study the concept of proper education.

- To study the relation between women empowerment and education for attaining goal of women.

\section{RESULT AND DISCUSSION: WOMEN EMPOWERMENT AND EDUCATION.}

The term 'Empowerment' which has become so popular in the context of women has emerged out of the world 'power' - to empower is to authorize, to make powerful. ${ }^{1}$ It is needless to say 
that a general awareness of the exploitation of women empowerment on various fields like social, cultural, political and economic fields for which strong protest is revealed in Women's Liberation Movement. It was emerged in the United States since the early 1970s. It is clear that nobody can think about goal without own empowerment. But women of human race are getting various problems on it. It is not only problem of females but also problem of the ultimate development of all people. In this sense women empowerment are necessary for all. Real education takes necessary part for getting empowerment. Education is simply one of the fundamental activities of human race. It can popularize any thing including women empowerment to society. So it is essential for new generation to continue the same tradition. Similarly, Peter Worsely (1949-69) stated, that a large part of our social and technical skills are acquired through deliberates institution which we call education. According to Jawaharlal Nehru, "Education of boy is Education of one person, but Education of a girl is Education of the entire family."2

This social institution has a great social importance for spread of knowledge. It can make awareness in every corner which can make person to be is to be fit. Cole stated that education changes the horizon, standards and perspectives of people. The horizon acceptable to a person at one time in his life may, as a result of learning be highly unacceptable at another time. One becomes dissatisfied with the existing state of his knowledge, with the conditions under which he lives, with his social situations and with his previous goals and the mean he has developed for achieving them. He not only becomes dissatisfied, he seeks new knowledge of new sets of conditions and relationships which are not only more satisfying to him but more worthwhile to others and to the social system in which he lives.

In ancient India Bhisma stated in the Mahabharata,

\section{"striyastu manam arhanti \\ Ta marnayata manavah \\ Paricarya namaskaryas \\ Tadayatta bhabantu vah"}

It means that woman is a human being who deserves proper respect. God adore that land where women are worshipped.

At present stage, woman education is scattering as an encouragement by which they can think for getting their original nature of empowerment. All education systems are not capable to spread knowledge of empowerment. Empowerment is a nature of Soul. So education system can't know empowerment without metaphysical basis. S.S.Chandra and R.K.Sharma in Philosophy of Education stated that the concept of self is the basis of the development of character, the central aim of education. Similarly Socratic statement 'know thyself and be thyself' is the universally acknowledged aim of education. So this type of education is necessary for getting empowerment of all. Indian culture basically emphasizes harmony of man, woman and the world while Western culture has made too much of man's desire to overpower Nature.

In the Rgveda which is explained, "The wife and husband, being the equal halves of one substance, are equal in every respect, therefore both should join and take equal parts in all works, religious and secular." 4 This type of teaching should be used in the education system. The term 'empowerment' denotes capacities and capabilities without which no one can develop own potentialities to realize the origin, inherent nature of the best self. It includes voluntary action which is the postulate of morality. It has freedom of choice to take independent decision which is a positive way of bliss. Empowerment of women like this can think or perform any actions for getting own highest peace. Empowerment opens the door of true knowledge. True knowledge is bliss while ignorance is bondage. Women getting empowerment try to acquire the concept 'I want to be who I am'. Its simple meaning that they try to get the original and 
inherent nature of the self through their empowerment. Empowerment is a real nature of each individual woman. The dictionary meaning of empowerment is to give power, to give capacity to perform some physical or mental action, to delegate authority, to give legal rights, to enable, to entitle, to invest with powers. The process of gaining control over the resources and self, which determines power, can be called empowerment. Actually, the concept of empowerment refers to the concept of freedom. In that sense it does not synonym power in terms of domination over others but certainly in terms of the efficiency and capacity to develop their ability for getting control over the complex material and non-material resources. Empowerment and education are actually co-related. So education system can take the main role for acquiring women empowerment, because it can spread knowledge of empowerment to all corners of woman. The report of the Independent Commission on International Development Issues under the Chairman of Willy Brandt in 1980 on 'Women Society' stated that Women progress needs to be treated as a conscious element in every programme directed towards development, the most basic of all needs is the right to participate in change and to share in the income.

Education can spread that equal participations in the technical, industrial and professional streams are necessary for women empowerment. According to Radhakrishnan this education should be mainly spiritualistic on which materialistic elements are found. In this sense education insists on both knowledge and wisdom. Real empowerment lies in getting freedom of mind. It is within us which inherent nature of self. Education can only spread before man what is right or wrong. But deciding is up to them. It is very significant that a woman can't be empowered after getting external power such like social, political power if she has no highest reasoning, pure consciousness and spiritual outlook. Self is the only real source of all aspects. Real empowered persons are humanistic for which they do not exploit empowerment of any other people. There is Plato's similar view that the purpose of education was not as it were to fill empty vessel, but to turn our eye of the soul towards the light. In this sense some women were empowered in the Upanisadic period. The conversation between Gargi and Yajnavalkya is its certain proof. In the court of king Janaka, Gargi was synonym in learning and intellect to the great greatest sage Yojnavalkya. It can be inferred, that time was aware of the educative power of women for which parents eager to get scholarly sons and daughters. "The dialogue between Gargi andYajnavakya is its proof. Gargi was a learned sage who took part in the discussion of highest truth with other sages in the court of King Janaka when other scholar sages were defeated by Yajnavalkya, Gargi challenged him, and consequently a very scholarly debate began in which Yajnavalkya was declared as victorious by Gargi." Awareness of empowerment should be taught among parents by vocational courses or informal courses. Education for women empowerment is needed as a special orientation including special cultural function. Moreover, all persons should support on a principle-based foundation of scientific rationalism and human rights specially the rights of women's education.

\section{CONCLUSION}

Proper education is needful for women empowerment. Some of proper educations is stated as follows. Bal Gangadhar Tilak in his Gospel of Karma-yoga clearly stated that ultimate goal of man is fully dependent on freedom from all kinds of bondage or exploitation. He established that freedom or empowerment is birth-right of each individual. Festivals of noble life such as Shivaji Festival inspire people for self-empowerment. It makes a united effort. Like Gita he realized that nishkamakarma is the only way to remove exploitation or bondage. Arjuna following this karma removed exploitation and got empowerment. Nishkamkarma is a ceaseless action through the help of jnana and Bhakti. He has no any desire to result. But he must be highest rational. He gets an eternal energy through the harmony of jnana, Bhakti and karma which can easily acquire empowerment. According to Immanual Kant moral person does not use other person as means. I have to conclude through existentialism. Its founder Jean-Paul 
Sartre in his psychological novels and plays stated in recent time that man's own inner self or existence is only real. It can be known to intuition. It is free from any bondage or exploitation. Man's freedom can't be exploited or arrested or attacked by others. In that sense he stated every man is the maker of his own luck or freedom or empowerment.

\section{REFERENCES}

[1] Kashyap, Sushanta K.,\& Goswami, Nandita, Economic Empowerment of Women in the North East, www.barbhagcollege.org, mail-barbhagcollege@gmail.com,p.15

[2] Siddhashrama,B.P., Problems and Perspectives of Social Philosophy, Published by Girish Sarma, local Organising Secy, $4^{\text {th }}$ Conference, ICSP-2004,P.326-27. 